\title{
Kinetics of bupivacaine after clonidine pretreatment in mice
}

Previous studies have reported that clonidine pretreatment causes an increase in the local anaesthetic activity of bupivacaine. This study was designed to document possible changes in the pharmacokinetic behaviour of bupivacaine and its main metabolite, desbutylbupivacaine, PPX, in mice afier a single, $0.1 \mathrm{mg} \cdot \mathrm{kg}^{-1}$, injection of clonidine. Kinetic variables of bupivacaine were determined after a single $20 \mathrm{mg} \cdot \mathrm{kg}^{-1}$ ip dose of bupivacaine in controls (Group I) and in clonidine ( 0.1 $\mathrm{mg} \cdot \mathrm{kg}^{-1}$ ip) pretreated mice (Group 2). The maximal concentration in serum (Cmax, $2.553 \pm 0.862 \mu \mathrm{g} \cdot \mathrm{ml}^{-1}$ versus $0.962 \pm 0.141 \mu \mathrm{g} \cdot \mathrm{ml}^{-1}$ for. Groups 2 and 1 , respectively, $P$ $=0.01$ ) and the area under the concentration curve (AUC, $3.530 \pm 0.330 \mu \mathrm{g} \cdot \mathrm{ml}^{-1} \cdot \mathrm{hr}^{-1}$ versus $1.755 \pm 0.252$ $\mu \mathrm{g} \cdot \mathrm{ml}^{-1} \cdot \mathrm{hr}^{-1}$ for Groups 2 and 1 , respectively, $P<0.01$ ) of bupivacaine were higher in clonidine pretreated mice while the Clearance $(\mathrm{Cl})$ was decreased in clonidine pretreated animals $\left(0.603 \pm 0.054 \mu \mathrm{g} \cdot \mathrm{ml}^{-1}\right.$ versus $1.264 \pm 0.447 \mu \mathrm{g} \cdot \mathrm{ml}^{-1}$ for Groups 2 and 1, respectively, $P<0.01$ ). The ratio of $A U C$ $P P X / A U C$ bupivacaine (which may partially indicate the rate of metabolism) was lower in presence of clonidine $(0.220 \pm$ 0.019 against $0.425 \pm 0.033$ for Groups 2 and 1 , respectively, $\dot{P}<0.01$ ). Our data indicate decreased metabolism in the clonidine-treated mice which suggests altered hepatic metabolism of bupivacaine by clonidine. This may explain the previously reported enhanced anaesthetic activity of bupivacaine in the presence of clonidine.

De précédents résultats nous ont permis de mettre en évidence une augmentation significative de l'activité anesthésique locale de la bupivacaine chez la souris après traitement par la clonidine. Le présent travail a pour but de rechercher si l'asso-

\section{Key words}

ANAESTHETICS, LOCAL: bupivacaine; PHARMACOLOGY: pharmacokinetics, clonidine; SYMPATHETIC NERVOUS SYSTEM: clonidine.

From the Laboratoire de Pharmacologie Médicale, Faculté de Médecine de Marseille, 27 Bld J.Moulin F 13385 Marseille cedex 5, France.

Address correspondence to: Dr. B. Bruguerolle.

Accepted for publication Ist January, 1995.
Bernard Bruguerolle MD PhD, Laurence Attolini Msc, Anne Marie Lorec Pharm D, Manon Gantenbein Msc ciation de clonidine (injection unique de $0.1 \mathrm{mg} \cdot \mathrm{kg}^{-1}$ de clonidine) à la bupivacaine peut modifier la pharmacocinétique de l'anesthesique local et de son principal métabolite, la desbutylbupivacaine (PPX). Les paramètres pharmacocinétiques de la bupivacaine ont été déterminés après injection d'une dose unique de $20 \mathrm{mg} \cdot \mathrm{kg}^{-1}$ ip de cet anesthésique local chez des animaux témoins (groupe 1) ou des animaux ayant reçu une injection préalable de clonidine $\left(0.1 \mathrm{mg} \cdot \mathrm{kg}^{-1}\right.$, groupe 2). Nos résuliats ont mis en évidence une augmentation significative du pic de concentration (Cmax, $2.553 \pm 0.862 \mu \mathrm{g} \cdot \mathrm{ml}^{-1}$ contre $0.962 \pm 0.141 \mathrm{\mu g} \cdot \mathrm{ml}^{-1}$ respectivement pour les groupes 2 et $1, P=0.01$ ) et de la surface sous courbe (AUC, $3.530 \pm 0.330$ $\mu \mathrm{g} \cdot \mathrm{ml}^{-1} \cdot \mathrm{hr}^{-1}$ contre $1.755 \pm 0.252 \mu \mathrm{g} \cdot \mathrm{ml}^{-1} \cdot \mathrm{hr}^{-1}$ respectivement pour les groupes 2 et $1, P<0.01)$ ainsi qu'une diminution significative de la clairance chez les animaux traités par clonidine $(0.603 \pm 0.054$ contre $1.264 \pm 0.447$ respectivement pour les groupes 2 et $1, P<0.01)$. En ce qui concerne la cinétique du métabolite, le PPX, le rapport AUC PPX / AUC bupivacaine (qui est un reflet partiel du taux de métabolisme) a été significativement abaissé en presence de clonidine $(0.220$ \pm 0.019 contre $0.425 \pm 0.033$ respectivement pour les groupes 2 et $1, P<0.01$ ). Nos résultats montrent donc une diminution de métabolisme de la bupivacaine par la clonidine pouvant expliquer l'augmentation de l'activité anesthésique locale constatée au cours de cette interaction.

This study is concerned with drug interactions with one of the most commonly used local anaesthetics, bupivacaine. The influence of benzodiazepines, flumazenil ${ }^{1-3}$ and calcium antagonists 4,5 on bupivacaine toxicity and kinetics has been recently documented.

Clonidine is an alpha $a_{2}$ adrenoceptor agonist widely used in anaesthesia practice which has been shown recently to have analgesic properties such as perioperative sedation and postoperative analgesia. Recently, there have been several studies of clonidine added to local anaesthetics. ${ }^{6-8}$ An enhanced anaesthetic activity of bupivacaine in presence of clonidine has been reported in mice (unpublished personal results).

The present work aims to document possible changes in the kinetics of bupivacaine and its main metabolite, desbutylbupivacaine (PPX) in mice after a single injection of clonidine. 


\section{Methods}

\section{Animals}

Adult male NMRI mice ( $30 \mathrm{~g}$ ) were housed five to a cage for a minimum of two weeks before use under controlled relative humidity (50-55\%), temperature $25 \pm 1^{\circ} \mathrm{C}$ and synchronisation by light-dark circle (L: $06.00 \mathrm{~h}-18.00$ $\mathrm{h}, \mathrm{D}: 18.00 \mathrm{~h}-06.00 \mathrm{~h}$ ) during the month of March.

\section{Protocol}

Two groups of 45 animals were used for this experiment: (1) a first group receiving bupivacaine alone $\left(20 \mathrm{mg} \cdot \mathrm{kg}^{-1}\right.$ ip), (2) a second group receiving the same dose of bupivacaine $30 \mathrm{~min}$ after a $0.1 \mathrm{mg} \cdot \mathrm{kg}^{-1}$ ip clonidine. For each group, bupivacaine was injected at $10.00 \mathrm{~h}$ to avoid possible circadian influence. ${ }^{9}$ Blood samples were collected by decapitation at $0.25,0.5,0.75,1,2,3,4,6$ and $8 \mathrm{hr}$ after drug administration.

\section{Determination of bupivacaine and pharmacokinetic variables}

Total bupivacaine and its main metabolite, desbutylbupivacaine (PPX), serum concentrations were determined by a specific gas liquid chromatographic method according to the technique of Bjork et al. ${ }^{10}$ modified by Lorec et al. "l The sensitivity of the method was $5 \mathrm{ng} \cdot \mathrm{ml}^{-1}$ and the reproductibility was good (coefficient of variation $<6 \%$ ). Clonidine did not interfere with the assay. Serum bupivacaine concentrations were plotted against time and pharmacokinetic variables were determined assuming a two-compartment open model. The Cmax and Tmax were derived directly from individual data, and $\beta$ phase elimination half-lives $\left(T_{1 / 2} \beta\right)$ and the area under the serum concentration curve $\left(\mathrm{AUC}_{0}{ }^{\infty}\right)$ were calculated. Total plasma clearance $(\mathrm{Cl})$ and total volume of distribution (Vd) were calculated according to the following equations: $\mathrm{Cl}=\mathrm{F} \times$ dose/ $\mathrm{AUC}$ were $\mathrm{F}$ is equal to 1 and $\mathrm{Vd}=\mathrm{Cl} / \beta$. The $\mathrm{Cmax}$, Tmax and the ratio AUC of PPX/AUC of bupivacaine were calculated. These variables were assessed according to a non-linear fitting method using PharmK ${ }^{\circledR}$ (SoftRes Inc. Atlanta, USA), a pharmacokinetic software for Macintosh computer. ${ }^{12}$ All data were summarized (means \pm SEM) and comparisons were done by Student's $t$ test.

Nota: Definition of the kinetic variables

Maximal concentration in serum $=\mathrm{Cmax}\left(\mu \mathrm{g} \cdot \mathrm{ml}^{-1}\right)$

Time to reach $\mathrm{Cmax}=\mathrm{T} \max (\mathrm{hr})$

Area under concentration curve $=\operatorname{AUC}\left(\mu \mathrm{g} \cdot \mathrm{ml}^{-1} \cdot \mathrm{hr}^{-1}\right)$

Volume of distribution $=\mathrm{Vd}(\mathrm{L})$

Total plasma clearance $=\mathrm{Cl}\left(\mathrm{L} \cdot \mathrm{h}^{-1}\right)$

$\beta$ phase elimination half-life $=T_{1 / 2} \beta(h r)$

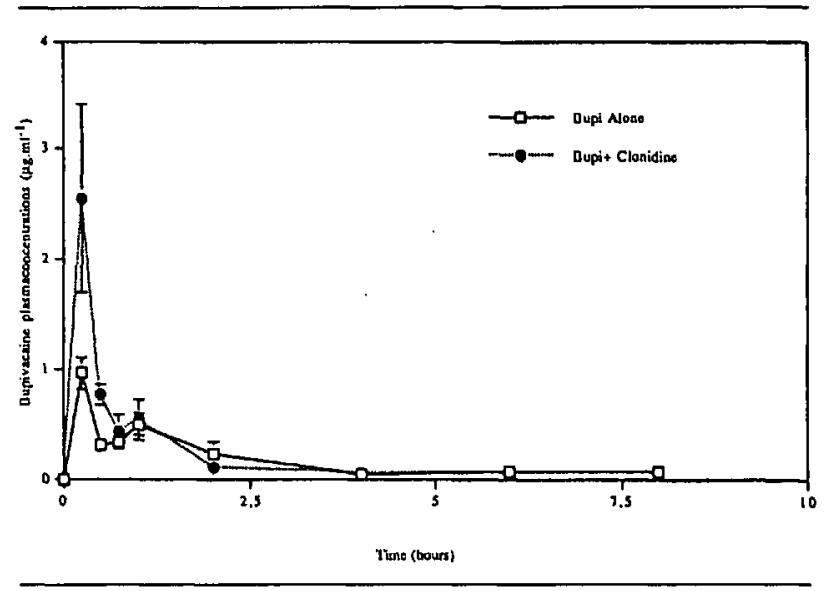

FIGURE 1 Bupivacaine plasma concentrations in mice receiving a single bupivacaine $20 \mathrm{mg} \cdot \mathrm{kg}^{-1}$ dose after a saline (Group 1) or a 0.1 $\mathrm{mg} \cdot \mathrm{kg}^{-1}$ single dose of clonidine (Group 2).

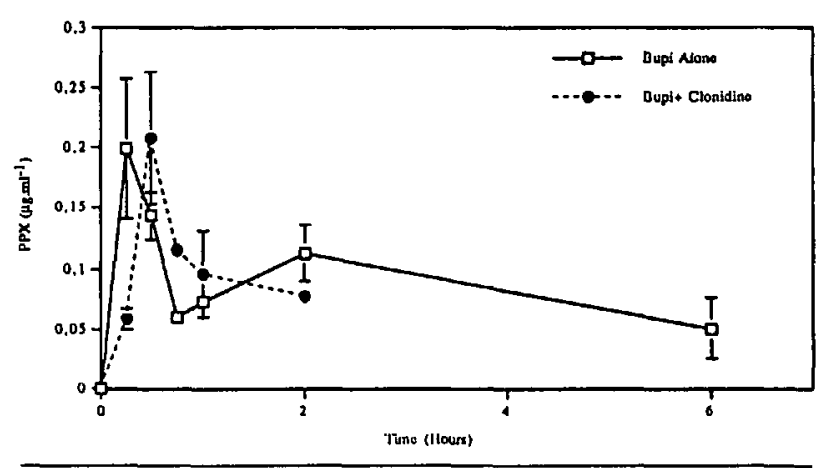

FIGURE 2 PPX plasma concentrations in mice receiving a single bupivacaine $20 \mathrm{mg} \cdot \mathrm{kg}^{-1}$ dose after saline (Group l) or a 0.1 $\mathrm{mg} \cdot \mathrm{kg}^{-1}$ single dose of clonidine (Group 2).

\section{Results}

Plasma bupivacaine and PPX concentrations, are plotted versus time in controls and clonidine pretreated animals (Figures 1 and 2).

Bupivacaine pharmacokinetic variables (Cmax, Tmax, AUC, $\left.\mathrm{Vd}, \mathrm{Cl}, \mathrm{T}_{1 / 2} \beta\right)$ are shown in Table I. Clonidine pretreatment increased bupivacaine $\mathrm{Cmax}(P=0.01)$ and AUC $(P<0.01)$ and decreased clearance $(P<0.01)$.

For PPX, there was a higher $T \max (P<0.05)$ and higher ratio AUC PPX/AUC bupivacaine $(P<0.01)$ in the clonidine pretreated group indicating decreased metabolism (Table II).

Thus, our data indicate a higher bioavailability of bupivacaine in presence of clonidine and a decreased clearance. Also, the decreased ratio of formation of PPX demonstrates a decrease in metabolism and elimination of bupivacaine after clonidine treatment. 
TABLE I Mean \pm SEM bupivacaine (B) pharmacokinetic variables in plasma without (B) or with pretreatment with clonidine $(\mathrm{B}+\mathrm{Cl})$

\begin{tabular}{|c|c|c|c|c|c|c|}
\hline & $\begin{array}{l}C \max \\
\mu g \cdot m t^{\prime}\end{array}$ & $\begin{array}{l}T \max \\
h r\end{array}$ & $\begin{array}{l}A U C \\
\mu g \cdot m t^{-1} \cdot h r^{-l}\end{array}$ & $\begin{array}{l}V d \\
L\end{array}$ & $\begin{array}{l}\mathrm{Cl} \\
\mathrm{L} \cdot h \mathrm{r}^{-1}\end{array}$ & $\begin{array}{l}T_{1 / 2} \beta \\
h r\end{array}$ \\
\hline Group 1 (B alone) & $0.962 \pm 0.141$ & $0.250 \pm 0.000$ & $1.755 \pm 0.252$ & $0.868 \pm 0.198$ & $1.264 \pm 0.447$ & $1.597 \pm 0.070$ \\
\hline Group $2(B+C)$ & $2.553 \pm 0.862$ & $0.250 \pm 0.000$ & $3.530 \pm 0.330$ & $0.374 \pm 0.278$ & $0.603 \pm 0.054$ & $1.192 \pm 0.302$ \\
\hline$P$ & $<0.05$ & NS & $<0.01$ & NS & $<0.01$ & NS \\
\hline
\end{tabular}

TABLE II Mean \pm SEM PPX pharmacokinetic parameters in plasma without (B) or with pretreatment with Clonidine $(\mathrm{B}+\mathrm{Cl})$

\begin{tabular}{|c|c|c|c|c|}
\hline & $\begin{array}{l}C \max \\
\mu g \cdot m t^{-1}\end{array}$ & $\begin{array}{l}T \text { max } \\
h r\end{array}$ & $\begin{array}{l}A U C_{0}^{6} \\
\mu g \cdot m t^{-l} \cdot h r^{-1}\end{array}$ & $\frac{A U C_{0}^{6} P P X}{A U C_{0}^{6} \text { bupivacaine }}$ \\
\hline Group 1 (B alone) & $0.209 \pm 0.053$ & $0.35 \pm 0.06$ & $0.526 \pm 0.105$ & $0.425 \pm 0.033$ \\
\hline Group $2(B+C l)$ & $0.208 \pm 0.055$ & $0.55 \pm 0.05$ & $0.347 \pm 0.043$ & $0.220 \pm 0.019$ \\
\hline$P$ & NS & $<0.05$ & NS & $<0.01$ \\
\hline
\end{tabular}

\section{Discussion}

The present work indicates, in the presence of clonidine, higher bupivacaine and PPX plasma concentrations and a decreased clearance of bupivacaine. The decreased formation of PPX in clonidine pretreated animals may indicate altered hepatic metabolism of bupivacaine by clonidine. Bupivacaine is known to be metabolized mainly to PPX by N-dealkylation in the liver and excreted in urine (10\%) as small amounts of pipecolylxylidine, unchanged drug (5\%) and other metabolites. ${ }^{13}$

Several studies have shown increased local anaesthetic concentrations when associated with clonidine. Nishikawa et al. ${ }^{7}$ reported that addition of clonidine to lidocaine for epidural anaesthesia increased plasma lidocaine concentrations. They speculated that greater plasma lidocaine concentrations suggested altered hepatic metabolism of lidocaine by clonidine. Also, Garty et al. ${ }^{6}$ reported that clonidine increased plasma concentrations of lidocaine while slowing its metabolism in rats and mice. De Kock et al. ${ }^{4}$ in a study on the influence of clonidine on the systemic toxicity of bupivacaine in rats reported that the mean plasma concentrations of bupivacaine were greater in the clonidine group than in the saline group. To our knowledge our study reports bupivacaine and PPX pharmacokinetic changes induced by clonidine for the first time.

The present study may partly explain the enhanced local anaesthetic activity of bupivacaine in presence of clonidine that has been observed in mice (unpublished personal results). Concerning a possible increase or decrease in the potential of toxicity of bupivacaine in pres- ence of clonidine, De Kock et al. ${ }^{14}$ reported that the toxicity of bupivacaine is not augmented by clonidine and Yokoyama et al. ${ }^{8}$ showed neither proconvulsant nor anticonvulsant effects of clonidine on lidocaine-induced convulsions. Thus, the possible potential toxicity of this drug interaction also needs to be clarified.

In conclusion, this study has documented a pharmacokinetic drug interaction between clonidine and bupivacaine suggesting an inhibition of bupivacaine metabolism. Further in vitro experimental studies will be required to determine the precise mechanisms involved.

\section{Acknowledgements}

This work was supported partly by a grant from The Fondation pour la Recherche Médicale. Special thanks to J. Mouchet for technical assistance.

\section{References}

1 Bruguerolle B, Emperaire N. Flumazenil and bupivacaineinduced toxicity: inverse agonist type activity. Life Sci 1991; 49: $185-8$.

2 Bruguerolle B, Emperaire $N$. Local anesthetics-induced toxicity may be modified by low doses of flumazenil. Life Sci 1992; 50: 185-7.

3 Bruguerolle B, Lorec AM. Lack of bupivacaine kinetic changes induced by flumazenil in mice. Life Sci 1993; 52: 165-7.

4 Bruguerolle B. Effects of calcium channel blockers on bupivacaine-induced toxicity. Life Sci 1993; 53: 349-53.

5 Bruguerolle $B$, Lorec $A M$. Bupivacaine kinetic changes induced by diltiazem in mice. Life Sci 1994; 54: 315-9. 
6 Garty M, Ben-Zvi Z, Hurwitz A. Interaction of clonidine and morphine with lidocaine in mice and rats. Toxicol Appl Pharmacol 1989; 101: 255-60.

7 Nishikawa T, Dohi S. Clinical evaluation of clonidine added to lidocaine solution for epidural anesthesia. Anesthesiolgoy 1990; 73: 853-9.

8 Yokoyama M, Hirakawa $M$, Goto $H$. Clonidine does not affect lidocaine seizure threshold in rats. Can $J$ Anaesth 1993; 40: 1205-9.

9 Bruguerolle B, Prat $M$. Temporal changes in bupivacaine kinetics. J Pharm Pharmacol 1987; 39: 148-9.

10 Björk $M$, Petterson $K-J$, Österlöf $G$. Capillary gas chromatographic method for the simultaneous determination of local anesthetics in plasma samples. J Chromatogr 1990; 533: 229-34.

11 Lorec AM, Bruguerolle B, Attolini $L$, Roucoules X. Rapid simultaneous determination of lidocaine, bupivacaine and their two main metabolites using capillary gas liquid chromatography with nitrogen phosphorus detector. Ther Drug Monit 1994; 16: 592-5.

$12 L u D R$, Mao F. An interactive program for pharmacokinetic modeling. J Pharmaceut Sci 1993; 82: 537-42.

13 Tucker GT, Mather LE. Clinical pharmacokinetics of local anaesthetics. Clin Pharmacokinet 1979; 4: 241-78.

14 De Kock $M$, Le Polain B, Henin D, Vandewalle $F$, Scholtes $J L$. Clonidine pretreatment reduces the systemic toxicity of intravenous bupivacaine in rats. Anesthesiology 1993; 79: 282-9. 